\title{
A new model for state-of-the-art leadership education with performance as a driving factor for future viability
}

\author{
Werner G. Faix ${ }^{1} \cdot$ Liane Windisch $^{1} \cdot$ Stefanie Kisgen ${ }^{1} \cdot$ Laurentia Paradowski $^{1} \cdot$ Felix Unger $^{2} \cdot$ Wilfried Bergmann $^{2}$. \\ Rudolf Tippelt ${ }^{3}$
}

Received: 18 June 2020 / Accepted: 11 July 2020 / Published online: 30 July 2020

(C) The Author(s) 2020

\begin{abstract}
The challenges of today's rapidly changing environment are tremendous. Almost every organization has new tasks; some must even completely modify their objectives, strategy, business focus, or business model. In addition to the necessity of managing processes as effectively and efficiently as possible, the topic of leadership has gained increasing importance. Thus, training and development programs aimed at preparing future generations of leaders have long been well frequented. However, current leadership education fails to meet the demands of either the present or the future, as our analysis shows. For this article, we have thoroughly researched current leadership education programs and comprehensively studied the pertinent literature. Based on this, we recommend goals, content, and methods for a state-of-the-art leadership education program. Our main findings demonstrate that leadership education should focus on (1) the development of competencies and their demonstrated performance, (2) personal development, and (3) the implementation of real-world projects as a form of inquiry-based learning. Furthermore, we precisely describe an evidence-based approach for an innovative study program: the newly developed 'Diploma of Performance and Leadership' (DPL). We end by giving an outlook on the program's implementation, which will be accompanied by empirical evaluation.
\end{abstract}

Keywords Leadership · Leadership education · Innovation · Personality · Personal development · Competencies · Performance

\section{Introduction}

The world is facing immense challenges at all levels: social, economic, global, national, and individual (Willke 2014). The future viability of our planet depends largely on how population growth, climate change, resource consumption, species extinction and the unequal distribution of wealth etc. can be managed. Conditions such as peace (Allison 2017), democracy, human rights, globalization, education, economic prosperity, participation of all citizens, and the realization of sustainability determine the future viability of

Werner G. Faix

faix@steinbeis-sibe.de

1 School of International Business and Entrepreneurship, Steinbeis University, Herrenberg, Germany

2 Alma Mater Europaea Founded by the European Academy of Sciences and Arts, Salzburg, Austria

3 Chair of General Pedagogy and Educational Research, Ludwig-Maximilians-University, Munich, Germany nations (Göll 2004). However, the future viability of companies and organizations depends on scientific and technological developments, i.e. on their ability to create InnovationQuality. ${ }^{1}$

There is a great need for innovation in all areas of society. These areas include food production (e.g. animal-free meat production, drinking water), mobility, digitalization and artificial intelligence (AI) (Mainzer 2016), energy supply, the redesign of humanistic education (Nida-Rümelin 2013), and last but not least, medical care. All innovative solutions to these problems must be sustainable.

To discuss the future viability of the earth, nations and organizations, we must first ask what 'future' means and discuss the capabilities we need to achieve this future. As philosopher Odo Marquard said, "the future needs the past" (Siemens 1994). Schumpeter said that every concrete development of an organization builds on previous development

\footnotetext{
${ }^{1}$ InnovationQuality denotes the degree to which there is a certain outcome, resulting from an innovation initiating, sustaining or safeguarding value creation. (Faix et al. 2014).
} 
Fig. 1 The future needs the past (own illustration)
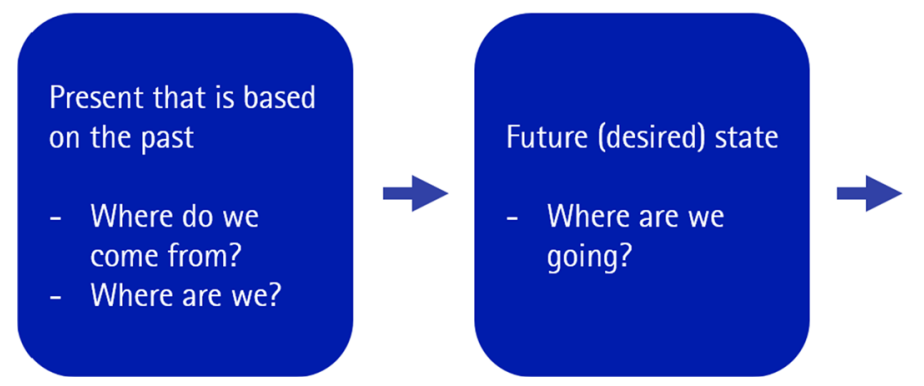

(Schumpeter 1934). If you do not know where you come from and where you are, it will be hard for you to determine where you want to go and what means and paths are necessary to get there (Faix and Mergenthaler, 2013). Figure 1 illustrates this premise.

Paths need a goal. In 1992 the United Nations Conference on Environment and Development (Behnen 2007; Gerold 2004; UNCED 1992) defined the goals of the international community as follows:

- To give all nations and states the necessary economic and cultural development opportunities

- To grant all people an appropriate amount of the world's resources in social equity

- To limit, in the interest of future generations, the use of natural resources, raw materials, flora and fauna to let the earth regenerate itself.

Achieving goals, realizing future viability and thus, according to Nida-Rümelin (2013), using sound reasons to create the future, depends crucially on what we refer to as leadership. This may be on a global, national, individual, corporate, or organizational scale.

For this, we need creative personalities who are willing and able to shape incremental innovations as well as capable of implementing disruptive and radical innovations that can meet the challenges mentioned above. Such creative personalities must have performance and leadership competencies (Faix et al. 2014; Faix and Mergenthaler 2013; Zillner and Krusche 2012).

The past century was characterized by population growth [in the second half of the twentieth century, the world population more than doubled despite China's onechild policy (Countrymeters.Info 2020)], unprecedented industrialization, and many wars. Influential people in national governments as well as in companies and organizations have played a decisive role in these events. Many people entrusted with leadership positions, however, were occupied with management tasks.

Although management tasks are undoubtedly important, if we wish to shape the future for the better, we need leadership personalities: people with leadership ability and leadership power. The challenges in society, politics, business, and science can no longer be mastered with classical management methods but require leadership. An excellent knowledge of tools and methods is characteristic for management. It is usually located in the field of economics. Gradually, however, some management tasks are being performed by AI systems (Frey and Osborne 2017). Leadership is an interdisciplinary discipline that consists of performance, innovation, and personality (Djalali, 2017; Faix et al. 1995; Faix and Laier 1991; Kisgen 2017; Mergenthaler 2017; Rosenstiel and Comelli 2015; Schumpeter 1942/2011)—although there are admittedly overlapping definitions (Drucker et al. 2014) (Figs. 2, 3).

Leadership development requires the evolution of competencies, performance, and personality (Kisgen 2017). Competencies are defined as the ability to act in a self-organized manner in situations involving complex, often chaotic systems that have open-ended problems and likewise require open-ended decisions. Competencies are thus the dispositions needed for self-organization. Knowledge and qualifications are the prerequisites for developing competencies and transferring them to various practical contexts (Erpenbeck and Rosenstiel 2003). Performance means exceptional proficiency that is already demonstrated (Preckel and Vock 2013). This intends that it is not a disposition, but a realized achievement, e.g. in form of an innovation. Innovation means that an idea has become a value-creating reality (Baregheh et al. 2009; Faix and Mergenthaler 2013). Personality refers to having personality and being a personality (Blumenthal et al. 2012). The connections between competencies, performance, and personality are shown in Fig. 4.

Due to the many challenges and sometimes serious changes such as digitalization and artificial intelligence, transformation processes are necessary in many areas. These often result in people developing insecurities or fears about the future (Bryson and Kime 2011). Therefore, leadership in such situations means not only thinking and shaping the future, but also offering those involved a high degree of security for their futures (Faix et al. 1994). The topic of leadership and the develop- 
Fig. 2 Leadership requirements (own illustration)

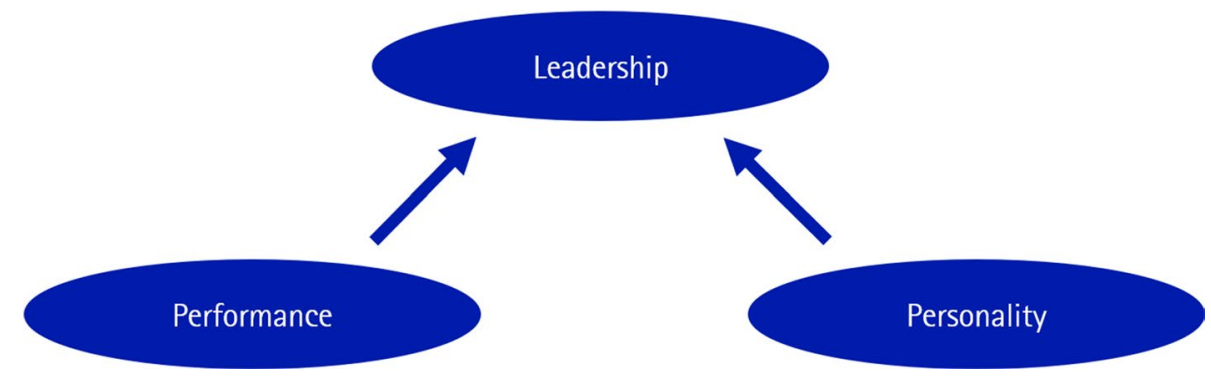

Philosophy

Pedagogy Educational Sciences

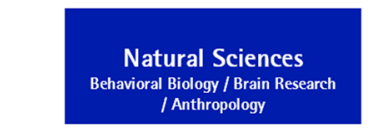

Sociology

Political Sciences

Psychology

Law

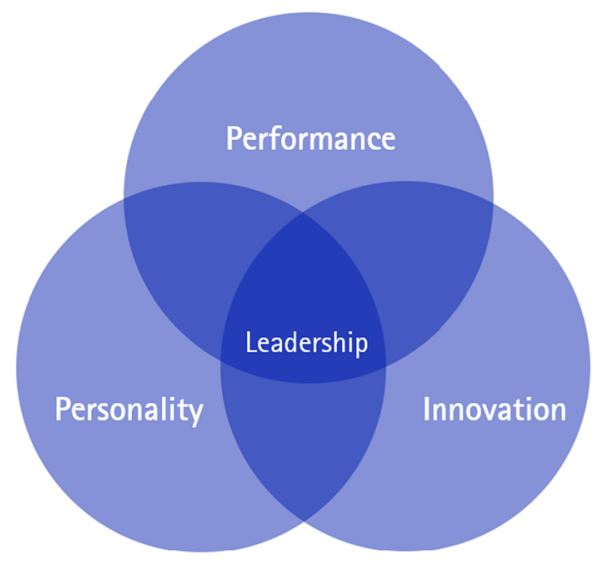

Economics

Futures Research

Informatics

Digitalization

Engeneering

Technology

\section{Rhetoric}

Fig. 3 The interdisciplinarity of leadership (own illustration)

ment of leaders must be rethought and redesigned for the reasons outlined above. Our research, analyses, and reflections, and the resulting exemplary and innovative post-post-graduate Master's program 'Diploma of Performance and Leadership' are described below.

\section{Leadership education}

\subsection{Definition of leadership}

The importance of leadership in today's world is obvious. However, what does leadership mean today? What will it mean in the future? One thing must be made clear: there is neither an ideal leader nor optimal leadership behavior that is valid for all situations (Tippelt 2013a). How must or how could concepts for the education and personal development of leadership personalities be defined and designed? Even though there are many definitions of leadership (Bass 2007), in our opinion they do not fully meet the requirements (of the present). We have therefore drawn up the following new general definition (Faix, A.-V., Faix, W. G., Kisgen, Mergenthaler in Faix et. al 2019)-also with regard to leadership education (Faix et al. 2019, 2020), and a holistic model for business leadership (Kisgen 2017).

Leadership means to lead oneself and human communities with personality—reasonably, responsibly, and ethically into an innovative and creative future in open and complex situations under unclearly defined and dynamic conditions while always considering the framework conditions and collective rationality.

Some explanations must be given for the above:

- Leading means being the reason why people want to actively achieve a common (new) goal (Mergenthaler 2017).

- Reasonably, responsibly, and ethically means having good (structural) reasons for creating sustainable positive developments for the community, creating value for one's society, and conserving nature (Benedikt 2009; Huber 
Fig. 4 Model of personality (based on Faix and Mergenthaler 2013; Mergenthaler 2017)

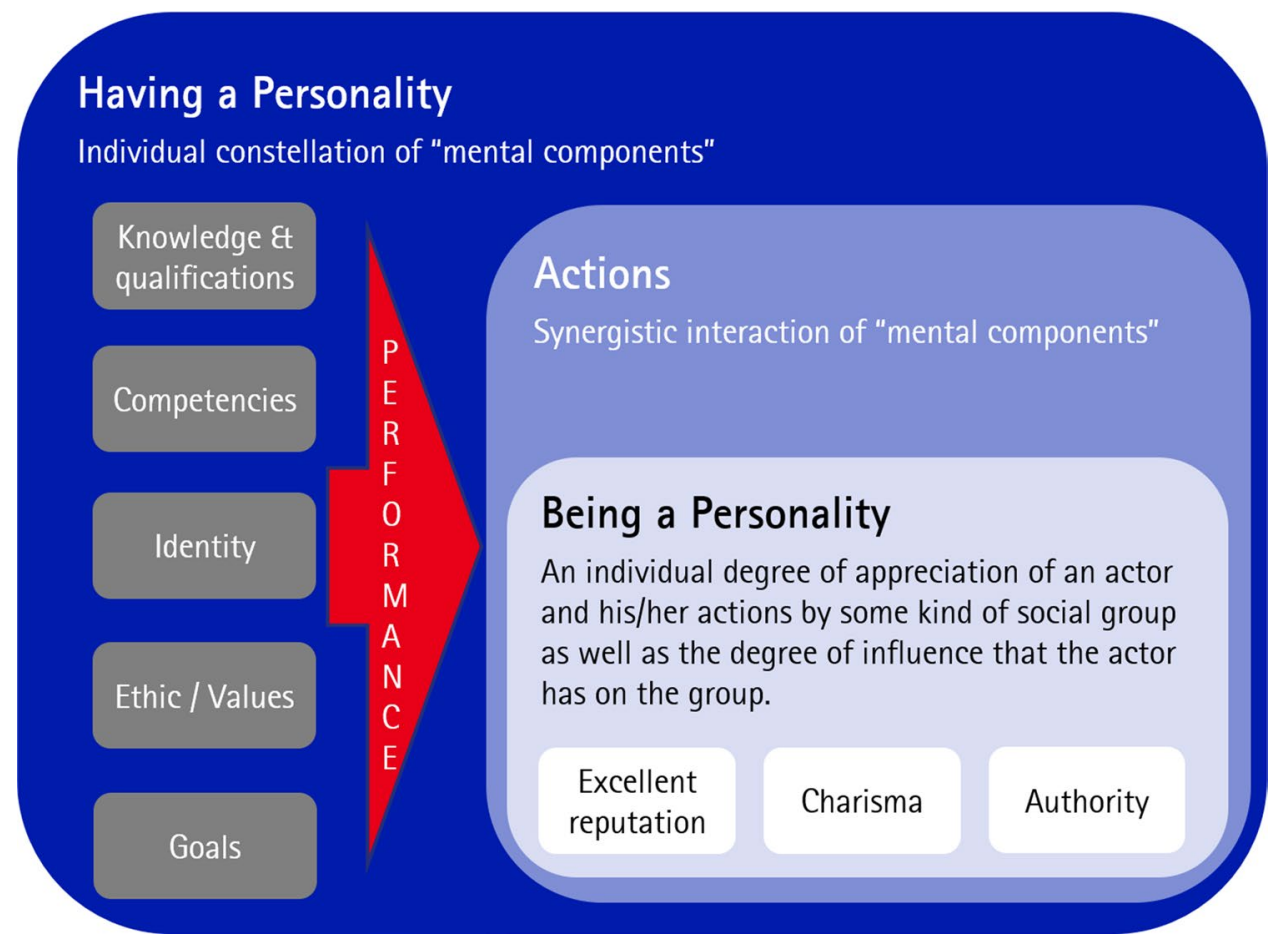

2013; Neubert 2013; Nida-Rümelin and Özmen 2006; Niedner 2013; Sommer 2016).

- Creating value for society means fulfilling humanistic educational ideals in the context of one's own possibilities and goals. It should not be understood as instrumentalism (Nida-Rümelin 2013).

- Leading communities means creatively shaping their future. In our complex and dynamic world, it presupposes/requires a clear vision of potential future scenarios as well as goals derived from these (for which one takes personal responsibility) (Kisgen 2017; Mödinger et al. 2016).

- An innovative and creative future implies more added value.

- Collective rationality means that as many stakeholders as possible participate cooperatively to achieve common goals (Wiedemann 2008).

- Human communities: organizations, companies, research groups, political parties etc. as well as their sub-communities and networks (Dinter 2001).

Kisgen (2017) developed the holistic model of business leadership shown in Fig. 5. It includes several essential aspects. Creative personalities contribute to a sustainable corporate development by implementing innovations. This implies that creative personalities are not only able to identify, set, and achieve innovation (and personal) goals, but that they also possess business leadership competencies. Creative personalities are also able to implement InnovationQuality and consequently shape the future. Business leaders act in a complex sociocultural context with its multiple reciprocal influences (Kisgen 2017).

\subsection{Leadership education requirements}

Many institutions and programs declare leadership development as one of their objectives. This also includes some MBA programs (Klimoski and Amos 2012; Pfeffer 2011). However, their curricula are usually very similar (Segev et al. 1999). Management content is their main focus; leadership plays only a secondary role (Djalali 2017). In the course of its history, the MBA has focused on technical and social skills. From 1990 onwards, its goal was to adapt qualifications to prevailing economic needs (Djalali 2017). Today, this important area of management must be expanded to include leadership within the framework of leadership education. Companies are also convinced that competency requirements will change significantly in the future (Weiß 2017).

Kisgen (2017) set the following requirements for the educational goals of tertiary leadership education: Familiarization with scientific education, personal and competency development, contributions through real-world challenges, goal-setting and achievement, creation and utilization of networks. (Kisgen 2017) The development of the creative personality is an overarching educational ideal that plays a role in all the educational goals mentioned. Kisgen (2017) described personality as an ideal that can be shaped. This thesis builds on Faix and Mergenthaler (2013), who defined knowledge, qualifications, and competencies as constructs for the independent development of a creative personality. 


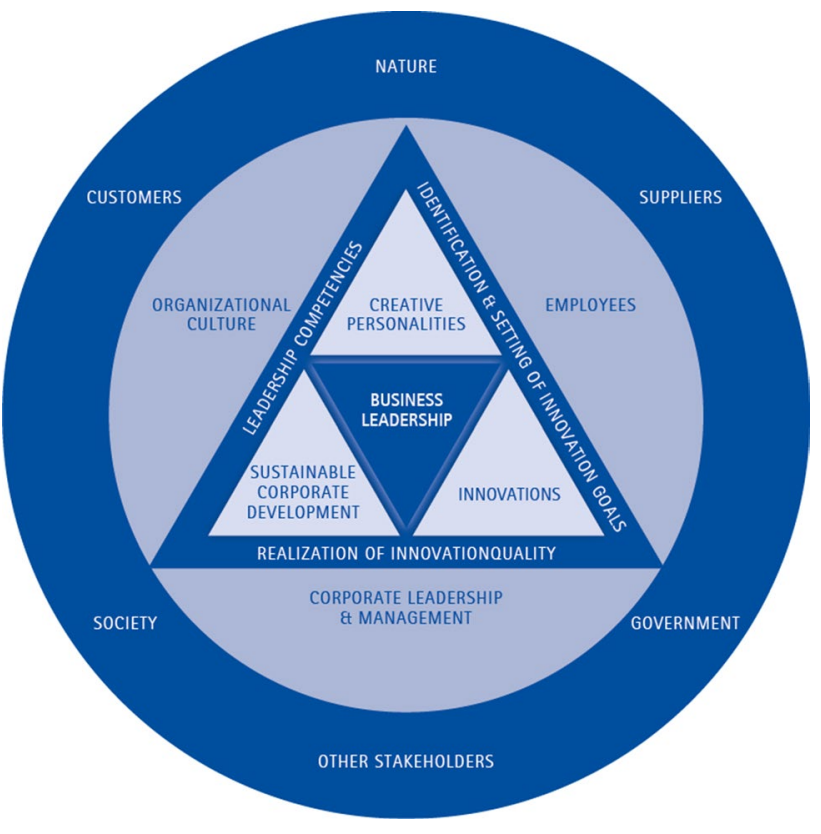

Fig. 5 Business leadership—a holistic model (Kisgen 2017)

Kisgen (2017) also defined the content and methods that should be applied in the context of leadership education:

- Innovation

- Entre- and intrapreneurship

- Goal setting

- Leadership knowledge

- International and intercultural exchange

- Real-world conditions

- Competency tests and feedback

- Reflection

Based on these and other research findings, we have compiled a collection of requirements for contemporary (leadership) education, as shown in Table 1.

Kisgen (2017) has further considered current educational programs in the tertiary sector in her work. She examined the curricula of 15 exemplary Master's programs selected from highly ranked business schools in regard to their educational content, educational methods, pedagogical environment, evaluation, educational goals and personal development. The results show that none of the Master's programs pursues all educational goals; five business schools meet two or three of the requirements. In reviewing the educational content, Kisgen (2017) found that no management program sufficiently meets the principles of a curriculum for business leadership education. For example, 27\% of Master's programs lack courses on innovation, business startup, management objectives, case studies and leadership development. Only $33 \%$ of the programs offer "innovation" as a mandatory course. Courses on "business start-up" are offered by $90 \%$ of the programs but mandatory in only four programs. Courses on "leadership development" are offered in all but two programs. "Management objectives" are not a separate component of any program. "Case studies", however, are available in each program. When looking at practical educational methods, Kisgen (2017) showed that "international/intercultural exchange" is present in all Master's programs. "Excursions", on the other hand, are only compulsory in $70 \%$ of Master's programs. Even though all programs include aspects of "real-world settings", these are not offered on a continuous basis or are limited to a few days/ weeks. "Systematic reflection" plays a role in all programs. The conclusion drawn from these reflections is that many current management programs apparently do not meet the requirements of future-oriented leadership education. They lack the real experiences and theoretical educational content that is necessary for leadership.

Kisgen (2017) also developed possible scenarios for future education in the field of business leadership education. She has posited the scenario "2030: Leadership trailblazer - grasping the 24/7 e-learning landscape and experiencing real-world settings": The fast pace of life and digital development confronts the future of education. In times of transformation, students would need to understand the practice of knowledge acquisition and scientific practices to participate in academic debates and recognize the benefits of scientific understanding. They would have the opportunity to generate innovation, achieve self-defined goals, develop leadership competencies, and create strong international networks. Based on knowledge and qualifications, the course of study would have to develop personalities. Theoretical exchange in the study program would take place via virtual reality. Interactive learning methods would motivate virtual learning. Further competencies would be created in real-world situations with students gaining practical experience in organizations. Transnational networking would enable interactions with people from all over the world (Kisgen 2017).

The research results show that shaping the future-no matter in which organization-should be called 'leadership' — not 'management'. To shape the future accordingly, new concepts for educating leadership personalities should be defined that fulfill the scientifically established requirements. Based on these findings, the following section introduces the post-postgraduate 'Diploma of Performance and Leadership' and describes how an innovative educational concept of tertiary leadership education, which sustainably uses the potential of future generations of leaders, can be designed in a time of constant change. Among other things, this educational concept postulates experience as an important component for the development of skills and the competencies of a leadership personality. 
Table 1 Contemporary requirements for higher (leadership) education

\begin{tabular}{|c|c|c|}
\hline \multicolumn{2}{|c|}{ Requirements } & $\begin{array}{l}\text { References } \\
\text { Faix et al. (1995) }\end{array}$ \\
\hline \multirow[t]{4}{*}{ Aims } & Development of personality & $\begin{array}{l}\text { Faix et al. (1995) } \\
\text { Pervin et al. (2005) } \\
\text { Spoun et al. (2005) } \\
\text { Rütter (2008) } \\
\text { Faix and Mergenthaler (2013) } \\
\text { Tippelt (2013a) } \\
\text { Neiman (2015) } \\
\text { Kisgen (2017) } \\
\text { Mergenthaler (2017) } \\
\text { Dalton (2018) } \\
\text { Nida-Rümelin and Weidenfeld (2018) }\end{array}$ \\
\hline & Competency development & $\begin{array}{l}\text { Faix and Laier (1991) } \\
\text { Faix et al. (1991) } \\
\text { Konegen-Grenier and Schlaffke (1994) } \\
\text { Erpenbeck and Rosenstiel (2003) } \\
\text { Erpenbeck (2004) } \\
\text { Heyse and Erpenbeck (2007) } \\
\text { Kisgen (2010) } \\
\text { Schönhuth (2011) } \\
\text { Blumenthal (2012a, b) } \\
\text { Tippelt (2013b) } \\
\text { Keim (2020) } \\
\text { Passarelli et al. (2018) }\end{array}$ \\
\hline & Performance Development & $\begin{array}{l}\text { Kisgen }(2017) \\
\text { Erpenbeck (2002) }\end{array}$ \\
\hline & Confidence for scientific judgement & $\begin{array}{l}\text { Pasternack (2008) } \\
\text { Pfeffer (2011) }\end{array}$ \\
\hline \multirow[t]{5}{*}{ Content } & Leadership theory & $\begin{array}{l}\text { Cube and Alshuth (1997) } \\
\text { Kisgen (2017) } \\
\text { Mergenthaler (2017) } \\
\text { Faix et al. (2019) }\end{array}$ \\
\hline & $\begin{array}{l}\text { Leadership frameworks: digitalization, AI, } \\
\text { globalization, sustainability, networks }\end{array}$ & $\begin{array}{l}\text { Jokinen (2005) } \\
\text { Waddock (2007) } \\
\text { Vila et al. (2012) } \\
\text { Mainzer (2016) } \\
\text { Petry (2016) } \\
\text { Brandes-Visbeck and Gensinger (2017) } \\
\text { Creusen et al. (2017) } \\
\text { Isada and Isada (2017) } \\
\text { Kreutzer et al. (2017) } \\
\text { Lesch and Kamphausen (2017) } \\
\text { Kuhlmann (2018) } \\
\text { Tavanti and Davis (2018) } \\
\text { Wagner (2018) } \\
\text { Cortellazzo et al. (2019) }\end{array}$ \\
\hline & Leadership ethics & $\begin{array}{l}\text { Bowen et al. (2006) } \\
\text { Pfeffer (2011) } \\
\text { Blumenthal et al. (2012a, b) } \\
\text { Nida-Rümelin (2013) } \\
\text { Huppenbauer (2017) } \\
\text { Faix (2020) }\end{array}$ \\
\hline & Innovation & $\begin{array}{l}\text { Vila et al. (2012) } \\
\text { Anderson et al. (2014) } \\
\text { Faix et al. (2014) } \\
\text { Isada and Isada (2017) }\end{array}$ \\
\hline & Entre- / Intrapreneurship & $\begin{array}{l}\text { Rasner et al. (1996) } \\
\text { Surie and Ashley (2008) } \\
\text { Kisgen (2017) }\end{array}$ \\
\hline
\end{tabular}


Table 1 (continued)

\begin{tabular}{|c|c|c|}
\hline \multicolumn{2}{|c|}{ Requirements } & \multirow{2}{*}{$\begin{array}{l}\text { References } \\
\text { Kisgen (2017) } \\
\text { Wang et al. (2018) }\end{array}$} \\
\hline \multirow{7}{*}{ Methods } & Goal orientation & \\
\hline & International / Intercultural skills & $\begin{array}{l}\text { Jokinen (2005) } \\
\text { Faix et al. (2006) } \\
\text { Bird et al. (2010) } \\
\text { Kisgen (2010) } \\
\text { Faix et al. (2013) } \\
\text { Kisgen et al. (2013) } \\
\text { Djalali (2017) } \\
\text { Kisgen (2017) }\end{array}$ \\
\hline & Reflection & $\begin{array}{l}\text { Kaplan (2007) } \\
\text { Crossan et al. (2013) } \\
\text { Dalton (2018) } \\
\text { Rubens et al. (2018) } \\
\text { Faix et al. (2019) }\end{array}$ \\
\hline & Real world settings & $\begin{array}{l}\text { Tippelt (1979) } \\
\text { Kreuzer and Lorenz (1984) } \\
\text { Markkula and Lappalainen (2009) } \\
\text { Tippelt and Reich-Claassen (2010) } \\
\text { Faix and Mergenthaler (2013) } \\
\text { Dávila Quintana et al. (2016) } \\
\text { Waddock (2016) } \\
\text { Kisgen (2017) }\end{array}$ \\
\hline & Experiments/active learning & $\begin{array}{l}\text { McHann and Frost (2010) } \\
\text { Freeman et al. (2014) } \\
\text { Wieman (2014) } \\
\text { Djalali (2017) }\end{array}$ \\
\hline & Online/E-learning & $\begin{array}{l}\text { Erpenbeck and Sauter (2007) } \\
\text { Acito et al. (2008) } \\
\text { Dräger and Müller-Eiselt (2017) }\end{array}$ \\
\hline & Group works & Dávila Quintana et al. (2016) \\
\hline
\end{tabular}

\section{Diploma of performance and leadership (DPL)}

The results of futures research and the findings of empirical studies presented before show that the existing management education system, its methods, and its contents are not designed to meet the current and future needs and expectations of our society.

Based on our findings, we have developed a study model that uses the didactic tools of the future to close the gaps in the development of performance and personal development. To educate future leaders, we must recognize the high importance of the (creative) personality in the context of leadership education, as already initiated in the humanistic educational tradition based on the Humboldt model (see Fig. 6).

Rütter (2008) describes the development of personality. Every human being is a person from birth and constantly develops potential through experiences, actions, education, etc. By implementing this potential, the creative personality becomes recognizable for human society (see Fig. 7).

The classical university education model, with its focus on theory, reality, and reflection, enables personal development as well as the development of qualifications, competencies, and performance. Complemented by personal identity, ethics and values, rationality, and responsibility as well as personal and entrepreneurial goals, the basis of leadership emerges as shown in Fig. 8.

\subsection{The Experience Based Curriculum (EBC) as state-of-the art didactics for leadership education}

The elements theory, reality and reflection are the core elements of the Experience Based Curriculum (EBC) developed by the School of International Business and 
Fig. 6 The elements of education (Faix et al. 2020)

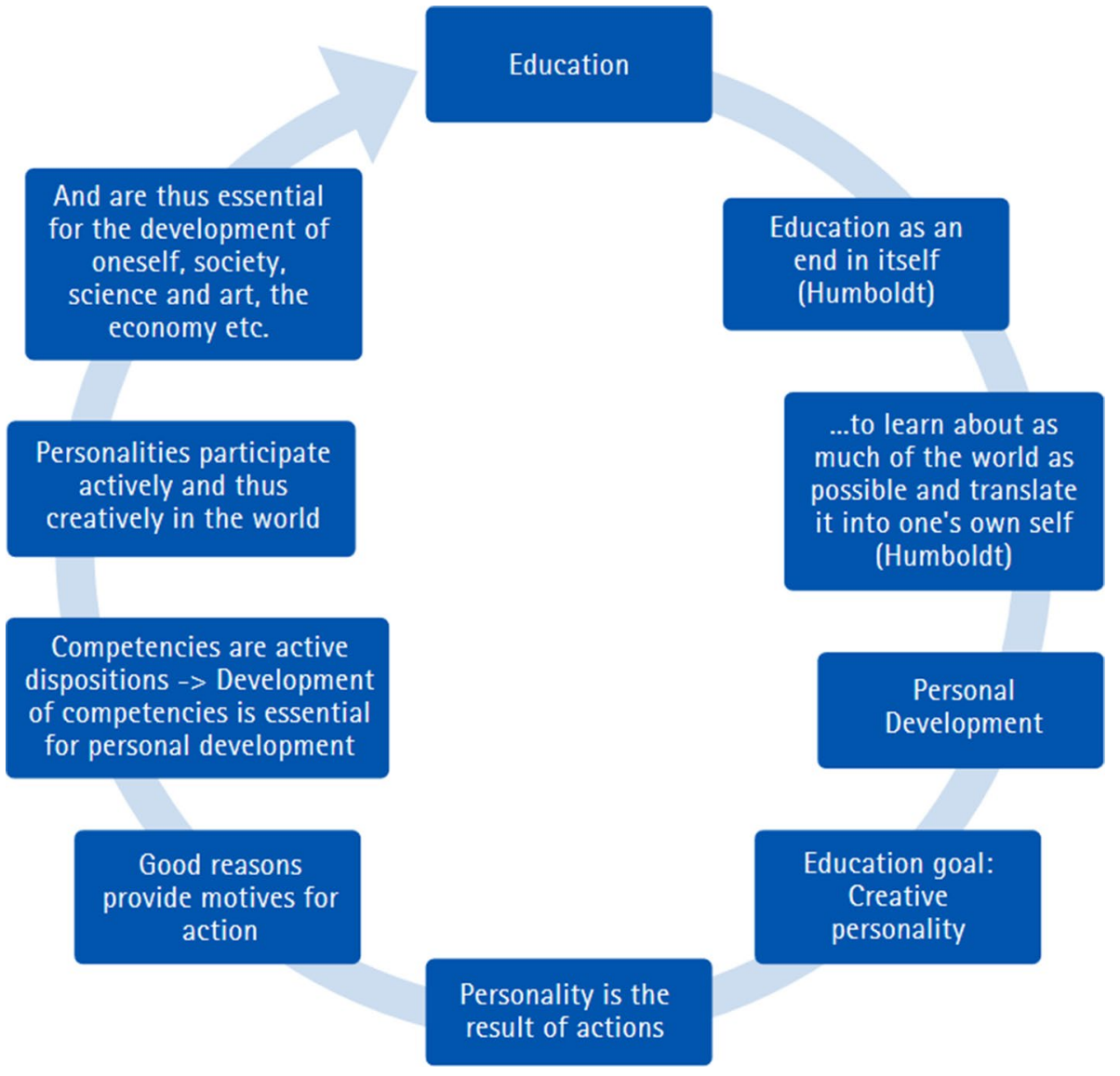

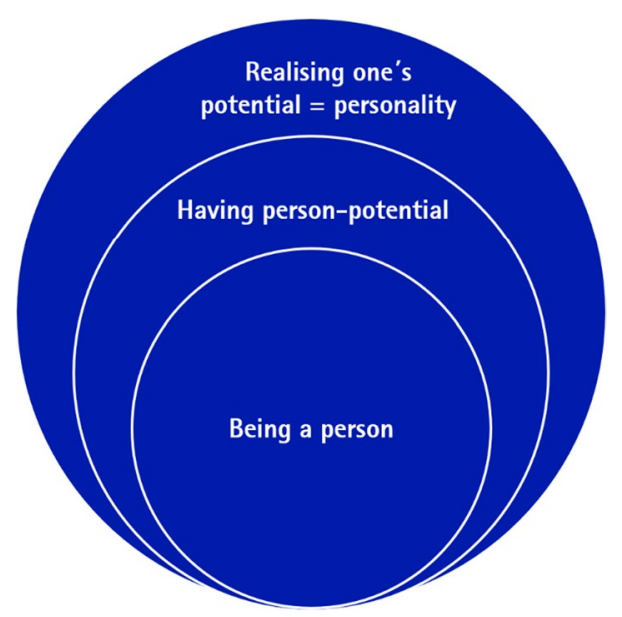

Fig. 7 The being of a person (Rütter 2008)

Entrepreneurship (SIBE). Several empirical studies show that this didactical methodology can positively influence the student's development.

Keim (2020) analyzed the evolution of key competencies within a longitudinal study. Self- and external assessments of over 600 students using $\mathrm{KODE}^{\circledR} \mathrm{X}$ competency measurements of 16 sub-competencies resulted in over 2200 measurements altogether. Keim (2020) found statistically relevant increases of the following competencies during the EBC program: innovative spirit, problem-solving, holistic thinking, decision-making, resilience (Keim 2020).

SIBE continually follows the careers of its graduates with evaluations. These show that (1) 95\% regard the EBC as good or very good, (2) $58 \%$ hold leadership positions three years after graduation, and (3) $9 \%$ have founded their own company as entrepreneurs (SIBE). With regard to the structure of the EBC, Djalali (2017) compared the didactic models of highly ranked international business schools. He showed that most of them give students far fewer opportunities for real-world experiences (e.g. field trips, company visits, projects) than SIBE's EBC, in which $50 \%$ of the curriculum consists of practical experience through the implementation of an innovation project (Djalali 2017). To fully realize the EBC's potential within a leadership education program, Mergenthaler (2017) conducted a comprehensive literature review. He concluded that for contemporary leadership education, the lifelong development of one's own personality is mandatory and therefore an important part of any curriculum (Mergenthaler 2017).

To define scenarios for the long-term future (2030) of business leadership education in tertiary education, a Delphi-based scenario study was carried out (Kisgen 2017). 105 


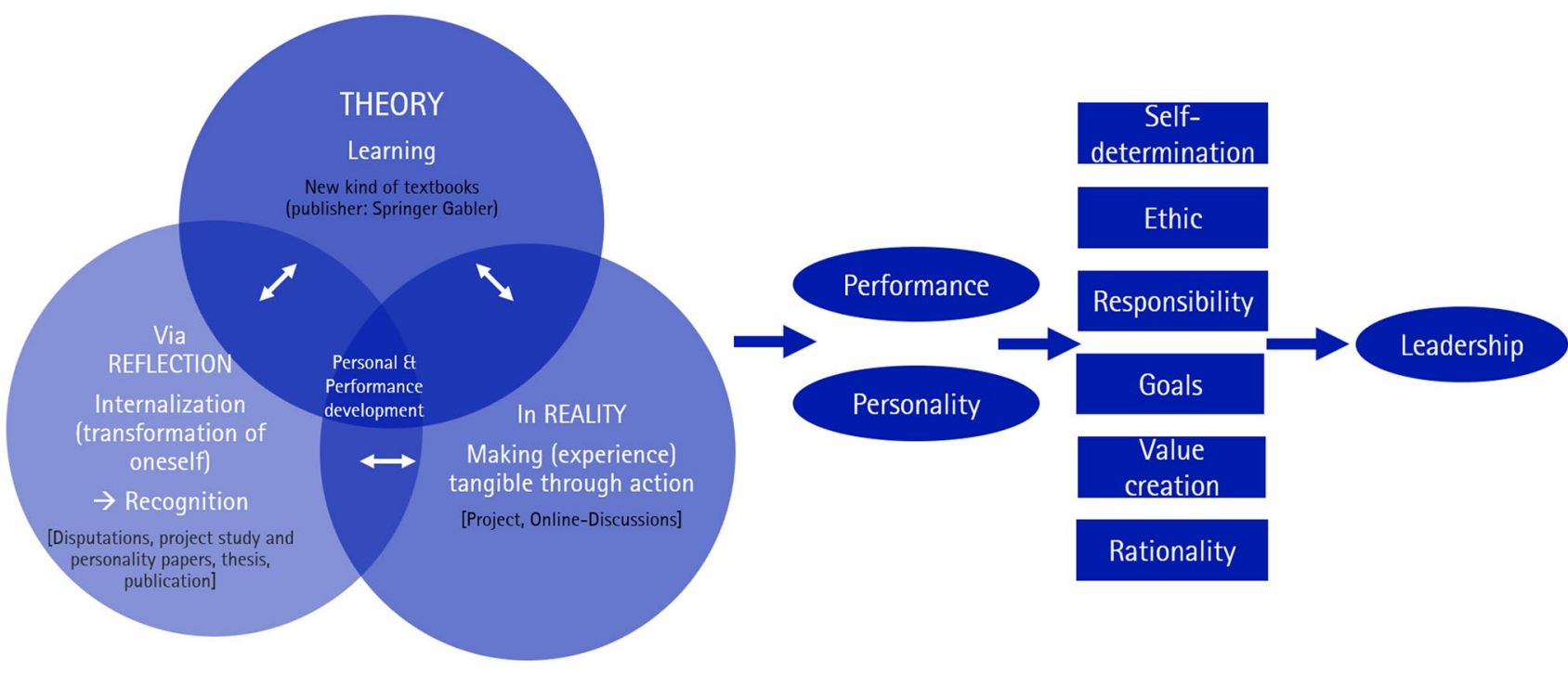

Fig. 8 Experience Based Curriculum: Theory-Reality-Reflection (based on Faix et al. 1995)

experts from 13 countries and 16 industries participated in this real-time Delphi survey. The results of the study significantly influenced the development of the DPL program.

Based on the Delphi survey as well as all the abovenamed empirical findings, which mainly examined postgraduate management programs using the EBC model, we developed a post-postgraduate program. This "Diploma of Performance and Leadership" builds on the successful EBC and offers an innovative didactic model for leadership education.

\subsection{Description of the study program}

The goal of the online study program "Diploma of Performance and Leadership" is to help students develop their performance and personal development and become leaders. The focus of the DPL is placed on leadership because for one, as explained in our definition, "self-leadership" is extremely important in any leadership practice. For another, leadership is becoming increasingly important in an age of massive change, as explained above. The challenges that await society in this context are extensive. Each person must be able to adapt in order to survive in a constantly changing environment, especially in the world of work. Therefore, the study program helps students examine problems in an interdisciplinary and transfer-oriented way so they can develop a wide range of solutions. The second focus of the program is performance. The development of performance must be carried out highly reflectively and with academic guidance. This allows students to develop their first results in an openended, scientifically based innovation project.

The study program addresses Master's graduates, doctoral candidates, future leaders in organizations, and young business founders. We believe that leadership competencies should be developed as early as possible to enable independent personal development. Building on this ability to "lead themselves", graduates can take on responsibility as personalities and offer their colleagues orientation in the future. At the same time, their achievements also benefit their society and increases its value. By 'society', we mean organizations, companies, research groups, political parties etc. and their sub-communities in all areas of social life: economy, science, politics, social and healthcare, defense, jurisprudence, theology, philosophy, etc. We emphasize the broad definition of 'society' because people's individual actions can positively influence their environment or even a large part of society.

The study model consists of the triad of theory, reality, and reflection. Since learning takes place in the context of real questions and problems, theory and reality are closely connected. Learning for written exams is not an unprecedented challenge and work on case studies is only a picture of the world, since the decisions to be made do not influence one's own reality. The DPL confronts students with a project that they work on independently-be it as part of a doctorate, as a trainee, or as an entrepreneur. The innovative focus of the projects, which can originate in any business department, is as multifaceted as their professional or scientific challenges. These may include scientific projects, innovation projects, growth strategies, cost optimization, restructuring, new management systems, the development of new target groups, the development of new products, etc. Project work functions according to the scientific principle of critic and rationality, in the sense of "Plan-Execute-Check and Revise", and applies to all projects (if not all of life) (Mentis 2014). During projects, students experience the 
consequences of their decisions. This completes the study model, in the sense that their own reflection gives them a corresponding increase of knowledge.

The implementation of core elements takes place at different levels. We have developed new (print) textbooks which builds the theoretical basis. They are approximately 80-120 pages in length, as this format seems to be particularly motivating for the acquisition of complex theoretical content. We have also designed them with the intention of creating a positive user experience. The decision in favor of textbooks follows the findings that students better process learned content when derived from a textbook. Furthermore, students prefer them to digital e-books (Woody et al. 2010). To deepen the knowledge foundation, the books are supplemented with QR codes that reference relevant scientific (open access) literature. To develop leadership personalities, we provide content on performance, leadership, competencies, digitization, transformation, innovation, futures studies, ethics, sustainability, and networks (Fig. 9).

Accompanying colloquia serve to discuss theoretical knowledge. These help students achieve a deeper understanding and simultaneously help them acquire the academic and scientific ability to debate. Regular feedback and critical questioning in the study group enable reflection. The lecturers (Academic Success Counselors = ASC) who accompany the discussions explicitly evaluate the quality of the students' contributions. Students provide further scientific reflection of their work in the form of project study papers (PSP), which present the progress of their respective projects. In addition to receiving feedback from the lecturer, fellow students also contribute their own experiences by assisting each other and following the progress of each other's projects. Analyzing different projects from various perspectives and fields promotes interdisciplinary thinking. Later, students apply the theoretical knowledge to their projects. This brings the dimension of "reality" into focus. Students experience the strategies, actions, or measures that are suitable for their projects. They also see the results of their projects-i.e. their success or failure. In the further processing of the project, the project phases are repeated to attain the end result (Fig. 10). Since this result relates to one's own reality, students achieve a much deeper learning success, which also influences the development of their personality.

\subsection{Structure of the study program}

The Diploma of Performance and Leadership is a one-year post-postgraduate Master's program with a total of 60 ECTS credits. The "Performance" and "Leadership" modules are completed in the first semester. The PSP of the first module deals with the topic "Setting Goals and Strategy"; the PSP of the second module is written on "Leadership". The second semester addresses the module "Development of

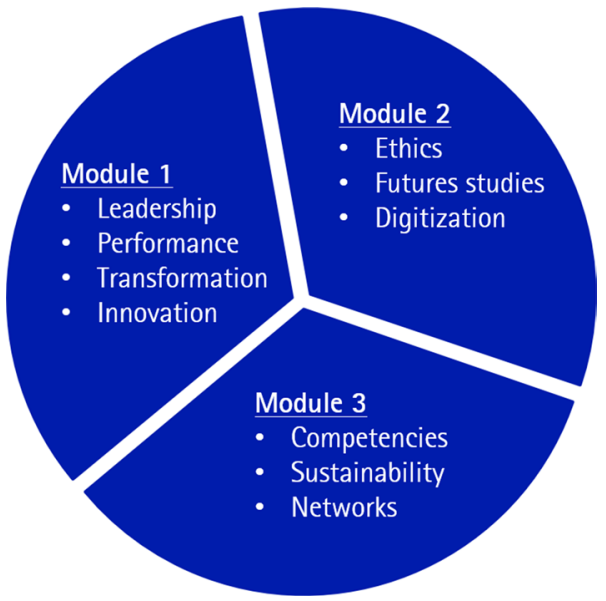

Fig. 9 Educational basics and their implementation in the study program (own illustration)

Personality". The required PSP deals with the student's personality and considers the student's own competencies and performance. Students are graded for each module based on their corresponding PSP as well as participation in the online colloquia. In the second half of the second semester, the main task is to write the final paper. It can have different formats, depending on the student's project and working environment. The student's goal should be to publish a paper in a scientific journal, announce an invention or patent, or develop a business plan for the foundation of a start-up. Only in exceptional cases will the preparation of a classic Master's thesis be allowed. Oral examinations will be required in conjunction with all variants of the final exam.

\subsection{Didactic elements of the study program}

Within a study group, which usually consists of 15 participants, students independently learn the content of the textbooks associated with the respective module. These books focus on topics relevant for leaders, such as digitalization and futures studies, so that the knowledge gained can be used to successfully master future challenges. The textbooks are didactically structured to provide students with a thorough examination of the subject. The knowledge is then expanded during the colloquia led by lecturers. The task of the lecturers is not to check whether students have learned the contents of the textbooks. This becomes clear in the discussions. Instead, the lecturers provide supervision, guide the discussions through reflective questions, and can supplement the debate with current issues from politics, economics, science, etc. The colloquia take place online and asynchronously in a private study group forum. Both students and lecturers contribute to this in the form of video sequences. Even if there is no assessment of the knowledge, contributions within the colloquia are mandatory and their 
Fig. 10 Textbooks within the modules (own illustration)

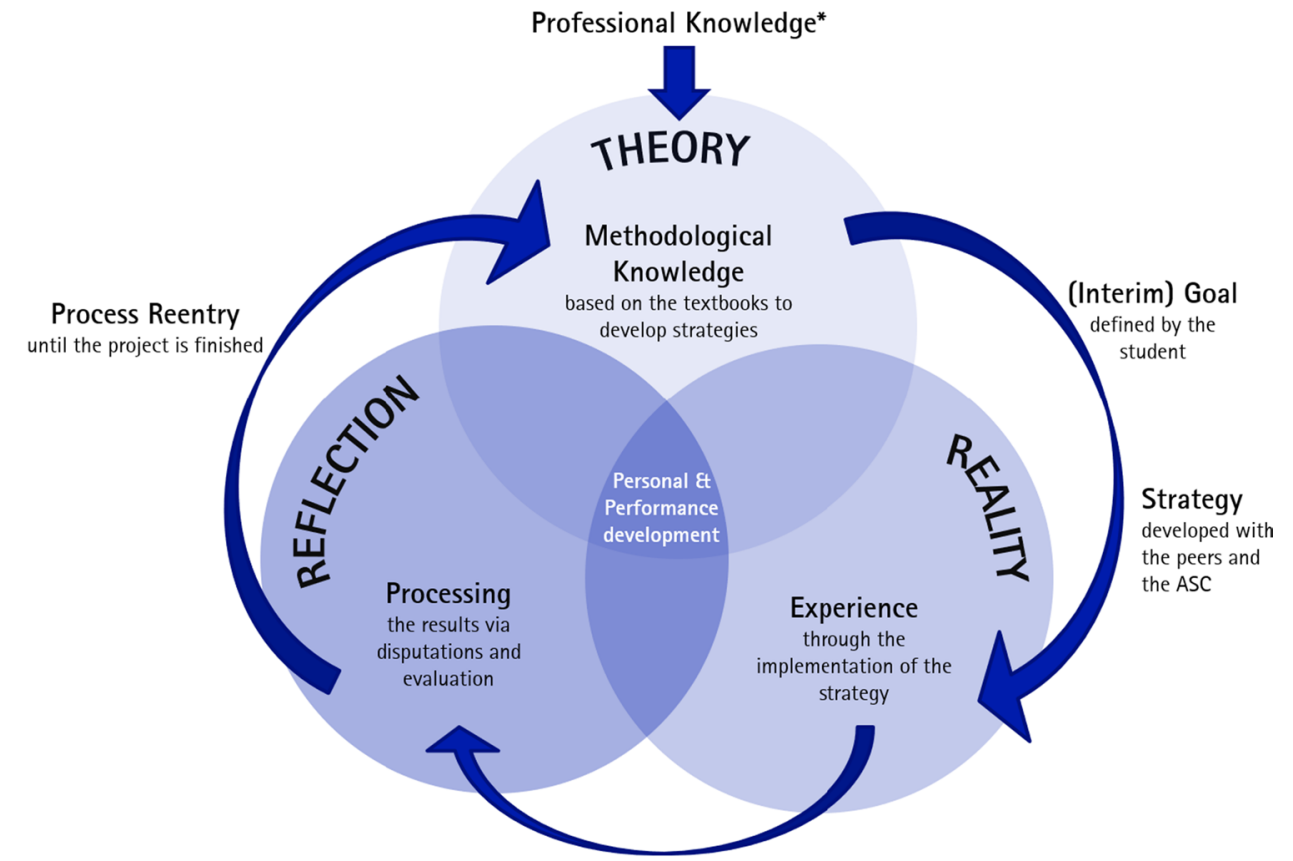

*needs to be available and expandable in post-graduate students based on individual responsibility and depending on the respective project quality and quantity are considered in the evaluation of the associated PSP.

In addition to the acquisition of theoretical content, each student's own real-world project plays a major role. The project should result in scientific and/or economic benefit and can have the following characters: knowledge-gaining, optimizing, new, disruptive, radical, or beneficial. The project options are diverse:

- Scientific projects, e.g. part of a dissertation (in any discipline)

- Innovation projects in a company or organization from all areas and industries, e.g. digitalization, new business models, new management structures, new networks, new or further developed products/new or further developed services, new organizational structures, new production processes, optimization/radicalization of the supply chain, etc.

- Business models for a start-up or for founding a company

We have developed the suitable project heuristics for the systematic execution of projects. These are divided into eight phases that must be accomplished one after the other (see Fig. 11). They are the basis of the so-called project loops of the study model. The starting point is always reflection on the reasons and purposes of a project, followed by the analysis of the actual situation, considering internal and endogenous factors. This analysis is followed by a consideration of the general conditions and external or exogenous factors. Subsequently, the findings of the two analyses are combined. Based on this, the students develop the project goal and derive a strategy. The implementation of the strategy is followed by a control of the achievement of the goal and purpose.

This means that students are responsible for acquiring the technical knowledge necessary for the respective project. Since all of them have an academic Master's degree, this is not a great challenge. The theoretical foundations for the innovation projects are systematically discussed and deepened in colloquia during the studies, thus giving the individual students the confidence to apply the "right" strategy to achieve their respective goals.

The discussions are followed by the experimental phase of applying the theory in experiments or in the reality of innovation development. The experimental phases are structured systematically and logically during study by the heuristics of the strategic triangle and the project loops. The students document each planned action and each intermediate result in short form and discuss them with two fellows under the supervision of the ASC. This constellation changes every three months. These documented interim evaluations are presented and critically discussed in the respective working group, again under the supervision of the ASC, whose main role is to ask WH questions: who, what, when, where, why.

During the 1-year study program, students go through three project loops (see Fig. 12); the first develops an understanding of methods among the students and systematically leads to the definition of the study project. The second project loop evaluates the interim result; the third ends with the final project. Analogous to the colloquia on the textbooks, the project loops are also forums for discussion, debate, and 

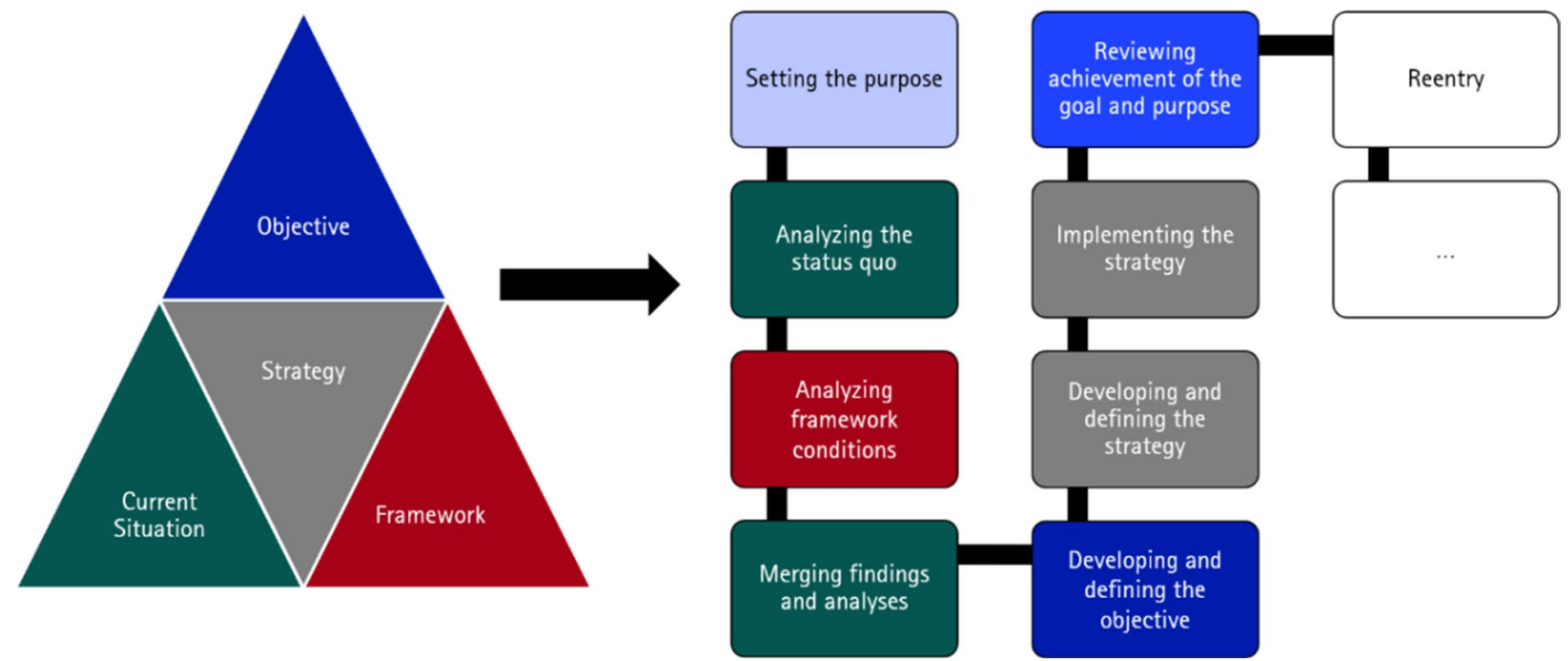

Fig. 11 The Strategic Triangle and the project loops (Faix et al. 1994; 2008; 2019)

dispute. To enable closer exchange between the students, each study group for the project colloquia consists of three participants. In this constellation, each student prepares a weekly status report of a maximum of one page on his or her project progress. The other two group members provide qualified written feedback on it. This creates a close interaction between the fellow students; insight into the projects of the others promotes an interdisciplinary approach to problems. The groups are rearranged every three months to allow the examination of further projects. Each project loop includes the submission of a PSP, which is an essential part of the exams. The PSPs must be circa 10 pages long and deal with the phases of the project loops. While the first two PSPs are presented and defended in front of the entire study group, the third PSP, which deals with personal performance and competency development, is a confidential essay for which the student receives individual feedback from the lecturer.
The KODE®X competency assessment according to Keim et al. (2010) and Heyse and Erpenbeck (2007) connects this profound examination to one's own personality. This scientifically validated procedure focuses purely on the measurement of observable and emerging competencies. It diagnoses and establishes existing competencies and provides specific action items and suggestions for the competency development of individuals. This assessment takes place at the beginning of the study program to determine a status quo.

The objective of the DPL study program is to advance performance and personal development. It thus builds the basis for students to emerge as future leaders. Students acquire the necessary competencies by going through complex situations that can cause a sense of emotional destabilization and involvement. Performance development is possible based on theory, competencies, identity and ethics,
Fig. 12 Project loops (own illustration)

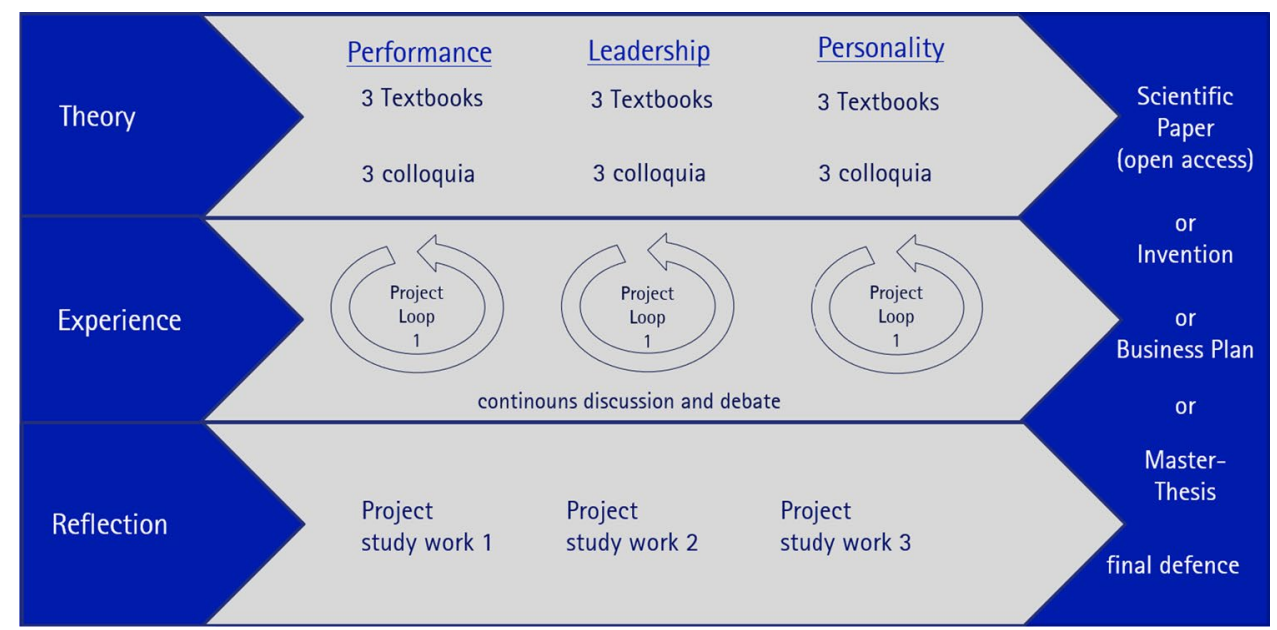


through self-defined goals, and the desire to achieve these goals at all times. Personal development takes place in a reflective manner and accompanied by academic support.

\section{Discussion and outlook}

In order to master the challenges arising from the enormous changes of our time, leaders are needed who can define strategies in open-ended situations and who are able and willing to act (Initiative Neue Qualität der Arbeit [INQA] 2016). This requires radical innovations and new approaches to solutions. Competencies are an important prerequisite for developing innovations, but for companies it is particularly important to realize them by demonstrating performance (Pongratz 2007). Performance is important both at the organizational and the personal level (Sonnentag 2008). However, many leaders lack the analytical skills to meet real challenges (Pfeffer 2011). This shows the necessity for systematic and successful leadership education.

In this context, Brown (2019) calls for programs that do not follow the latest trends. He also questions long-established methods and finds that it is important to develop evidence-based approaches and monitor their success. We have developed and designed the Diploma of Performance and Leadership study program based on scientific findings. Leadership development takes place by using the following didactic tools: action learning (Volz-Peacock et al. 2016), work-based learning (Raelin 2004), real-world projects as well as post-event reviews (DeRue et al. 2012) and reflection.

While working on their projects, students execute actions that demonstrate performance. This real-world performance is extremely valuable when evaluating a person as a leader, because intelligence and personality tests cannot reasonably assess the future ability of people in companies (Boyatzis 1982). Demanding and challenging real-world projects also lead to the development of a value-creating leadership personality, which is the primary goal of university education (Kisgen 2017).

The study program will start at the end of $2020^{2}$ in cooperation with the Alma Mater Europaea founded by the European Academy of Sciences and Arts and with Springer as the publisher of the textbooks. The introduction will be accompanied by an empirical study that will review the program and allow conclusions on its achievement of objectives, quality, and further development. The results of this study will be made available in publications.

Funding No funding source is available.

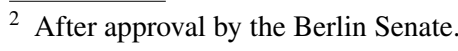

Availability of data and material The dataset supporting the conclusions of this article is available upon request.

\section{Compliance with ethical standards}

Conflict of interest The authors declare that they have no competing interests.

Ethical approval statement This study was carried out in accordance with the recommendations of the Ethical Principles of Psychologists and Code of Conduct of the American Psychological Association (APA).

Open Access Dieser Artikel wird unter der Creative Commons Namensnennung 4.0 International Lizenz veröffentlicht, welche die Nutzung, Vervielfältigung, Bearbeitung, Verbreitung und Wiedergabe in jeglichem Medium und Format erlaubt, sofern Sie den/die ursprünglichen Autor(en) und die Quelle ordnungsgemäß nennen, einen Link zur Creative Commons Lizenz beifügen und angeben, ob Änderungen vorgenommen wurden. Die in diesem Artikel enthaltenen Bilder und sonstiges Drittmaterial unterliegen ebenfalls der genannten Creative Commons Lizenz, sofern sich aus der Abbildungslegende nichts anderes ergibt. Sofern das betreffende Material nicht unter der genannten Creative Commons Lizenz steht und die betreffende Handlung nicht nach gesetzlichen Vorschriften erlaubt ist, ist für die oben aufgeführten Weiterverwendungen des Materials die Einwilligung des jeweiligen Rechteinhabers einzuholen. Weitere Details zur Lizenz entnehmen Sie bitte der Lizenzinformation auf http://creativecommons .org/licenses/by/4.0/deed.de.

\section{References}

Acito F, McDougall PM, Smith DC (2008) One hundred years of excellence in business education: what have we learned? Bus Horiz 51(1):5-12. https://doi.org/10.1016/j.bushor.2007.08.004

Allison G (2017) Destined for War: Can America and China Escape Thucydides's Trap?. Houghton Mifflin Harcourt, Boston

Anderson N, Potočnik K, Zhou J (2014) Innovation and creativity in organizations. J Manag 40(5):1297-1333. https://doi. org/10.1177/0149206314527128

Baregheh A, Rowley J, Sambrook S (2009) Towards a multidisciplinary definition of innovation. Manag Decis 47(8):1323-1339. https:// doi.org/10.1108/00251740910984578

Bass BM (2007) Concepts of Leadership. In: Vecchio RP (ed) Leadership: understanding the dynamics of power and influence in organizations, 2nd edn. University of Notre Dame Press, Notre Dame, pp 3-22

Behnen J (2007) Die UNCED-Konferenz in Rio De Janeiro und die Agenda 21 (1992). Eine kritische Betrachtung (1. Aulage). GRIN Verlag, München

Benedikt XVI (2009) Caritas in veritate (29. Juni 2009). Edition Rosenberger. https://www.vatican.va/content/benedict-xvi/de/ encyclicals/documents/hf_ben-xvi_enc_20090629_caritas-inveritate.html. Accessed 16 June 2020

Bird A, Mendenhall M, Stevens MJ, Oddou G (2010) Defining the content domain of intercultural competence for global leaders. J Manag Psychol 25(8):810-828. https://doi.org/10.1108/02683 941011089107

Blumenthal I, Djalali A, Faix WG, Horne A, Keck G, Kisgen S, Mergenthaler J, Mezger P, Reichert SF, Rominger B, Sailer J, Wieczorreck J, Wittmann P (2012) Werte - Bildung - Ethikkodex (1. Aufl.). Steinbeis Edition, Stuttgart 
Blumenthal I, Faix WG, Hochrein V, Horne A, Keck G, Lenz R, Mergenthaler J, Sax S (2012) Über einige Fronten des War for Talents. In: Faix WG (Ed) Kompetenz, Persönlichkeit, Bildung/ School of International Business and Entrepreneurship. Werner G. Faix ... (Hrsg.); Bd. 4. Kompetenz: Festschrift-Prof. Dr. John Erpenbeck zum 70. Geburtstag (pp. 491-540). Steinbeis Edition, Stuttgart

Bowen C, Bessette H, Cham TC (2006) Including ethics in the study of educational leadership. J Coll Character. https://doi. org/10.2202/1940-1639.1241

Boyatzis RE (1982) The competent manager: a model for effective performance. A Wiley-Interscience publication. Wiley, New York

Brandes-Visbeck C, Gensinger I (2017) Netzwerk schlägt Hierarchie: Neue Führung mit Digital Leadership. Redline Verlag

Brown RP (2019) Holding higher education to account: measuring what matters in the development of students as leaders. J Charact Leader Dev 6(2):34-49

Bryson JJ, Kime PP (2011) Just an artifact: why machines are perceived as moral agents. In: Proceedings of the Twenty-Second International Joint Conference on Artificial Intelligence: Barcelona, Catalonia, Spain, 16-22 July 2011, 1641-1646. https://doi. org/10.5591/978-1-57735-516-8/IJCAI11-276

Cortellazzo L, Bruni E, Zampieri R (2019) The role of leadership in a digitalized world: a review. Front Psychol 10:1938. https://doi. org/10.3389/fpsyg.2019.01938

Countrymeters.info. (2020). Weltbevölkerung 2020-Weltbevölkerungsuhr. https://countrymeters.info/en. Accessed 16 June 2020

Creusen U, Gall B, Hackl O (2017) Digital leadership: führung in zeiten des digitalen wandels. Springer Gabler. https://doi. org/10.1007/978-3-658-17812-3

Crossan M, Mazutis D, Seijts G, Gandz J (2013) Developing leadership character in business programs. Acad Manag Learn Educ 12(2):285-305. https://doi.org/10.5465/amle.2011.0024A

Cube FV, Alshuth D (1997) Fordern statt Verwöhnen: Die Erkenntnisse der Verhaltensbiologie in Erziehung und Führung (9. Aufl.). Serie Piper: Bd. 949. Piper, München

Dalton C (2018) 'Reflection is embedded in my brain forever now!': personal development as a core module on an Executive MBA. Reflect Pract 19(3):399-411. https://doi.org/10.1080/14623 943.2018.1479690

Dávila Quintana CD, Mora J-G, Pérez PJ, Vila LE (2016) Enhancing the development of competencies: the role of UBC. Eur J Educ 51(1):10-24. https://doi.org/10.1111/ejed.12162

DeRue D, Nahrgang J, Hollenbeck J, Workman K (2012) A quasiexperimental study of after-event reviews and leadership development. Articles and Chapters

Dinter S (2001) Netzwerke: Eine Organisationsform moderner Gesellschaften? Wissenschaft im Tectum-Verlag. Tectum-Verl, Marburg

Djalali A (2017) A didactic perspective on leadership education. In: Dissertation [XXI, 237 Seiten]. Steinbeis Edition, Stuttgart

Dräger J, Müller-Eiselt R (2017) Die digitale Bildungsrevolution: Der radikale Wandel des Lernens und wie wir ihn gestalten können (3., aktualisierte Auflage). Deutsche Verlags-Anstalt, München

Drucker PF, Gebauer S, Simon H (2014) Was ist Management? Das Beste aus 50 Jahren (7. Aufl.). Econ. München

Erpenbeck J (2002) Kompetenz und Performanz im Bild moderner Selbstorganisationstheorie. In: Bundesinstitut für Berufsbildung. 4. BIBB-Fachkongress 2002. Berufsbildung Für Eine Globale Gesellschaft-Perspektiven Im 21. Jahrhundert.

Erpenbeck J (2004) Kompetenzentwicklung und Lernkultur im Bild moderner Selbstorganisationstheorien. In R. Brödel (Ed.) Erwachsenenbildung und lebensbegleitendes Lernen Grundlagen und Theorie: Vol. 1. Weiterbildung als Netzwerk des
Lernens: Differenzierung der Erwachsenenbildung, Bertelsmann, Bielefeld, pp 67-91

Erpenbeck J, Rosenstiel LV (Eds) (2003) Handbuch Kompetenzmessung: Erkennen, verstehen und bewerten von Kompetenzen in der betrieblichen, pädagogischen und psychologischen Praxis. Schäffer-Poeschel Verlag, Stuttgart

Erpenbeck J, Rosenstiel LV, Grote S (Eds) (2013) Kompetenzmodelle von Unternehmen: mit praktischen Hinweisen für ein erfolgreiches Management von Kompetenzen. Schäffer-Poeschel Verlag

Erpenbeck J, Sauter W (2007) Kompetenzentwicklung im Netz: New Blended Learning mit Web 2.0. Personalwirtschaft Buch. Luchterhand, Köln

Faix AV (2020) Innovating leadership education: how business schools and universities need to innovate sustainable strategies in leadership education. In: Introduction to sustainable development leadership and strategies in higher education. Innovation in higher education teaching and learning, vol 22. Emerald Publishing Limited, Bingley, pp 39-53

Faix WG, Buchwald C, Wetzler R (1991) Skill-Management: Qualifikationsplanung für Unternehmen und Mitarbeiter. Gabler Verlag, Wiesbaden

Faix WG, Buchwald C, Wetzler R (1994) Der Weg zum schlanken Unternehmen. Verl. Moderne Industrie

Faix WG, Keck G, Kisgen S, Mezger P, Sailer J, Schulten A (Eds) (2008) Management von wachstum und globalisierung: best practice. Steinbeis Edition, Stuttgart

Faix WG, Kisgen S, Heilmann S (Eds) (2013) Steinbeis-Edition. Globalisierungsmanagement deutscher Unternehmen: Gründe, Zielregionen, Formen, Hindernisse, Erfolgsfaktoren (1. Aufl.). Steinbeis-Stiftung, Stuttgart

Faix WG, Kisgen S, Mergenthaler J (2019) Leadership. Personality. Innovation: education and research at SIBE. Steinbeis Edition, Stuttgart

Faix WG, Kisgen S, Shah S, Faix AV (2020) Fostering creative personalities through real-world experiences. SIBE as representative examp. J Compet Based Educ (to be published).

Faix WG, Laier A (1991) Soziale Kompetenz: Das Potential zum unternehmerischen und persönlichen Erfolg. Gabler Verlag, Wiesbaden

Faix WG, Lau A, Schulten A, Zywietz T, Kisgen S (2006) Praxishandbuch Außenwirtschaft (1. Aufl.). Gabler Verlag

Faix WG, Mergenthaler J (2013) Die schöpferische Kraft der Bildung (2., überarb. Aufl.). Steinbeis Edition, Stuttgart

Faix WG, Mergenthaler J, Ahlers R-J, Auer M (2014) InnovationsQualität: Über den Wert des Neuen (1. Aufl.). Steinbeis Edition, Stuttgart

Faix WG, Rütter T, Wollstadt E (1995) Führung und Persönlichkeit: Personale Entwicklung. Executive master of business administration. Verl. Moderne Industrie, Landsberg/Lech

Freeman S, Eddy SL, McDonough M, Smith MK, Okoroafor N, Jordt H, Wenderoth MP (2014) Active learning increases student performance in science, engineering, and mathematics. Proc Natl Acad Sci USA 111(23):8410-8415. https://doi.org/10.1073/ pnas. 1319030111

Frey CB, Osborne MA (2017) The future of employment: How susceptible are jobs to computerisation? Technol Forecast Soc Chang 114:254-280. https://doi.org/10.1016/j.techfore.2016.08.019

Gerold S (2004) Nachhaltige Entwicklung. GRIN Verlag, München

Göll E (2004) Nachhaltigkeit als Herausforderung für Parlamente. Zeitschrift Für Parlamentsfragen 35(1):68-80

Heyse V, Erpenbeck J (Eds) (2007) Kompetenzmanagement: Methoden, Vorgehen, KODE® und KODE®X im Praxistest. Waxmann

Huber W (2013) Das Ende der Beliebigkeit in wirtschaftsorientiertem Denken-Ein Plädoyer für Autarkie und Empathie. In: Faix WG, 
Erpenbeck J, Auer M (Eds) Bildung, Kompetenzen, Werte (1st ed., pp. 815-838). Steinbeis Edition, Stuttgart

Huppenbauer M (2017) Leadership und Verantwortung: Grundlagen ethischer Unternehmensführung. Versus, Zürich

Initiative Neue Qualität der Arbeit (2016) Monitor "Führungskultur im Wandel - Kulturstudie mit 400 Tiefeninterviews".

Isada F, Isada Y (2017) An empirical study regarding radical innovation, research and development management, and leadership. Naše Gospodarstvo Our Econ 63(2):22-31. https://doi. org/10.1515/ngoe-2017-0009

Jokinen T (2005) Global leadership competencies: a review and discussion. J Eur Ind Train 29(3):199-216. https://doi. org/10.1108/03090590510591085

Kaplan RS (2007) What to Ask the Person in the Mirror. https://hbr. org/2007/01/what-to-ask-the-person-in-the-mirror. Accessed 16 June 2020

Keim S (2020) Kompetenzerfassung in der tertiären Bildung. Dissertation: Ludwig-Maximilians-Universität München, München

Keim S, Erpenbeck J, Faix WG (2010) Der Poffenberger-KODE®X. Die Entwicklung des Kompetenzmessverfahrens KODE®X an der School of International Business and Entrepreneurship (SIBE). In: Faix WG, Auer M (Eds) Talent, Kompetenz, Management (1st ed., pp. 401-435). Steinbeis Edition, Stuttgart

Kisgen S (2010) Kompetenzmanagement mit dem master of science in international management der SIBE. In: Faix WG, Auer M (eds) Talent, Kompetenz, Management (1st ed., pp. 163-261). Steinbeis Edition, Stuttgart

Kisgen S (2017) The future of business leadership education in tertiary education for graduates. Dissertation (1st edition, 2017) [XXI, 426 Seiten]. Steinbeis Edition, Stuttgart

Kisgen S, Dresen A, Faix WG (eds) (2013) International Management (1. Aufl.). Steinbeis Edition, Stuttgart

Klimoski R, Amos B (2012) Practicing evidence-based education in leadership development. Acad Manag Learn Educ 11(4):685702. https://doi.org/10.5465/amle.2012.0018

Konegen-Grenier C, Schlaffke W (eds) (1994) Praxisbezug und soziale Kompetenz: Hochschule und Wirtschaft im Dialog (Vol. 20). Dt. Inst.-Verl., Köln

Kreutzer RT, Neugebauer T, Pattloch A (2017) Digital business leadership: digitale transformation-Geschäftsmodell-innovationagile organisation — change-management. Springer Gabler. https ://doi.org/10.1007/978-3-658-11914-0

Kreuzer F, Lorenz K (1984) Leben ist Lernen: Von Immanuel Kant zu Konrad Lorenz ; ein Gespräch über das Lebenswerk des Nobelpreisträgers (Orig.-Ausg., 3. Aufl., 11.-14. Tsd). Serie Piper: Vol. 223. Piper, Wiesbaden

Kuhlmann P (2018) Künstliche Intelligenz: Einführung in Machine Learning, Deep Learing, Neuronale Netze, Robotik und Co (1. Auflage). Independently Published

Lesch H, Kamphausen K (2017) Die Menschheit schafft sich ab: Die Erde im Griff des Anthropozän (Originalausgabe, 4. Auflage). Komplett-Media, München

Mainzer K (2016) Künstliche Intelligenz-Wann übernehmen die Maschinen? Technik im Fokus. Springer

Mainzer K (2018) Wie berechenbar ist unsere Welt: Herausforderungen für Mathematik, Informatik und Philosophie im Zeitalter der Digitalisierung. essentials. Springer VS, Wiesbaden. https://doi. org/10.1007/978-3-658-21298-8

Markkula M, Lappalainen P (2009) New openings in universityindustry cooperation: Aalto University as the forerunner of European University Reform. Eur J Eng Educ 34(3):251-262. https://doi.org/10.1080/03043790902902922

McHann JC, Frost LA (2010) Integrating experiential learning into business courses: using learning journals to create living case studies. Am J Bus Educ (AJBE). https://doi.org/10.19030/ajbe. v3i8.464
Mentis M (2014) Science writing in the real world. For Ecosyst 1(1):2. https://doi.org/10.1186/2197-5620-1-2

Mergenthaler J (2017) Leadership Education-ein abduktiver Entwurf. Dissertation (1. Auflage) [XVII, 535 Seiten]. Steinbeis Edition, Stuttgart

Mödinger W, Mergenthaler J, Faix WG (2016) Zukunftsfähige Führung (1. Auflage). Steinbeis Edition, Stuttgart

Neiman S (2015) Warum erwachsen werden? Eine philosophische Ermutigung ((M. Bischoff, Trans.)) (Von der Autorin bearbeitete und erweiterte deutsche Ausgabe). Hanser, Berlin

Neubert H (2013) Kunst und Ethik unternehmerischer FührungEine selbstreflexive Annäherung. In: Faix WG, Erpenbeck J, Auer M (eds) Bildung, Kompetenzen, Werte (1st ed., pp. 839850). Steinbeis Edition, Stuttgart

Nida-Rümelin J (2013) Philosophie einer humanen Bildung (1. Aufl.). edition Körber-Stiftung

Nida-Rümelin J (2018) Unaufgeregter Realismus: Eine philosophische Streitschrift. mentis, Paderborn

Nida-Rümelin J, Özmen E (eds) (2006) Humanismus als Leitkultur: Ein Perspektivenwechsel. Beck, München

Nida-Rümelin J, Weidenfeld N (2018) Digitaler Humanismus: Eine Ethik für das Zeitalter der künstlichen Intelligenz (2. Auflage, Originalausgabe). Piper, München

Niedner B (2013) Spielführer im Unternehmen-Verhaltensbiologische Aspekte der Natürlichen Autorität eines Spielführers. In: Faix WG, Erpenbeck J, Auer M (eds) Bildung, Kompetenzen, Werte (1st ed., pp. 851-866). Steinbeis Edition, Stuttgart

Passarelli AM, Boyatzis RE, Wei H (2018) Assessing leader development: lessons from a historical review of MBA outcomes. J Manag Educ 42(1):55-79. https://doi.org/10.1177/1052562917 730105

Pasternack P (2008) Die Einheit von Forschung und Lehre. Deutsche Universitätszeitung DUZ-Magazin 2(2008):20-21

Pervin LA, Cervone D, John OP (2005) Persönlichkeitstheorien: Mit 33 Tabellen (5., vollst. überarb. und erw. Auff.). UTB für Wissenschaft: Vol. 8035. Reinhardt, München

Petry T (ed) (2016) Haufe Fachbuch. Digital Leadership: Erfolgreiches Führen in Zeiten der Digital Economy (1. Auflage). Haufe Gruppe

Peus C, Braun S, Hentschel T, Frey D (eds) (2015) Personalauswahl in der Wissenschaft: Evidenzbasierte Methoden und Impulse für die Praxis. Springer Science and Business Media

Pfeffer J (2011) Leadership development in business schools: an agenda for change. In: Canals J (ed) IESE business collection. The future of leadership development: Corporate needs and the role of business schools (pp. 218-237). Palgrave Macmillan, Basingstoke

Pongratz LA (ed) (2007) Bildung-Wissen-Kompetenz. Janus-Software-Projekte, Bielefeld

Preckel F, Vock M (2013) Hochbegabung: Ein Lehrbuch zu Grundlagen, Diagnostik und Fördermöglichkeiten (1. Aufl.). Hogrefe

Raelin J (2004) Don't Bother Putting Leadership into People. Acad Manage Executive 18(3):131-135

Rasner C, Füser K, Faix WG (1996) Das Existenzgründer-Buch: Von der Geschäftsidee zum perfekten Geschäftserfolg. Verl. Moderne Industrie, Landsberg/Lech

Rosenstiel LV, Comelli G (2015) Führung zwischen Stabilität und Wandel. Verlag Franz Vahlen, München. https://doi.org/10.15358 19783800650651

Rubens A, Schoenfeld GA, Schaffer BS, Leah JS (2018) Self-awareness and leadership: developing an individual strategic professional development plan in an MBA leadership course. Int J Manag Educ 16(1):1-13. https://doi.org/10.1016/j.ijme.2017.11.001

Rütter T (2008) Bildungsarbeit: Eine Betrachtung aus dem Anspruch personaler Existenz (1. Aufl.). Pro Business, Berlin

Schönhuth M (2011) Hexen gesucht: Beraterkompetenz und Beraterpersönlichkeit aus ethnologischer Sicht. In: Faix WG (ed) 
Kompetenz, Persönlichkeit, Bildung (1st ed., vol. 3, pp. 211224). Steinbeis Edition, Stuttgart

Schumpeter JA (1934) The theory of economic development. Harvard Economic Studies, Cambridge

Schumpeter JA (1942/2011) Capitalism, socialism, and democracy (2nd ed.). Martino, Mansfield

Schumpeter JA (1947) The creative response in economic history. J Econ Hist 7(2):149-159. https://doi.org/10.1017/S002205070 0054279

Segev E, Raveh A, Farjoun M (1999) Conceptual maps of the leading MBA programs in the United States: core courses, concentration areas, and the ranking of the school. Strateg Manag J 20(6):549-565. https://doi.org/10.1002/(SICI)1097-0266(19990 6)20:6<549:AID-SMJ39>3.0.CO;2-F

SIBE GmbH (2019) SIBE Employment Report 2019. https://www. magglance.com/Magazine/adfb9185e157ca2764d77cb806457f 55/white. Accessed 16 June 2020

Siemens AG (1994) Zukunft braucht Herkunft, München

Sommer AU (2016) Werte: Warum man sie braucht, obwohl es sie nicht gibt (1st ed.). J.B. Metzler, Stuttgart. https://doi.org/10.1007/9783-476-05498-2

Sonnentag S (2008) Job performance. In: Barling J, Cooper CL (eds) The sage handbook of organizational behavior: volume 1: micro approaches (pp. 427-447). SAGE, Los Angeles

Spoun S, Brüggenbrock C, Wunderlich W (2005) Studienziel Persönlichkeit: Beiträge zum Bildungsauftrag der Universität heute. Campus-Verl

Surie G, Ashley A (2008) Integrating pragmatism and ethics in entrepreneurial leadership for sustainable value creation. J Bus Ethics 81(1):235-246. https://doi.org/10.1007/s10551-007-9491-4

Tavanti M, Davis EB (2018) Integrating sustainability mindset and impact competencies in management education: directions, models and strategies. In: Stachowicz-Stanusch A, Amann W (eds) Contemporary perspectives in corporate social performance and policy. Fostering sustainability by management education (pp. 223-243). Information Age Publishing Inc., Charlotte

Tippelt R (1979) Projektstudium. Exemplarisches und handlungsorientiertes Lernen an der Hochschule. Kösel, München

Tippelt R (2013a) Bildung, Persönlichkeit und professionelle Führung. In: Faix WG, Auer M (eds) Kompetenz.Studium.Employability, Stuttgart, pp 233-252

Tippelt R (2013b) Bildungssituation im tertiären Bildungsbereich (Hochschulen): eine quantitative Perspektive aus Sicht der
Bildungsforschung. In: Faix WG, Auer M (eds) Kompetenz. Studium.Employability, Stuttgart, pp 217-231

Tippelt R, Reich-Claassen J (2010) Lernorte-Organisationale und lebensweltbezogene Perspekti. DIE-Report, 11-20.

Tippelt R, Schmidt-Hertha B (eds) (2018) Handbuch Bildungsforschung. Springer Fachmedien Wiesbaden, Wiesbaden. https ://doi.org/10.1007/978-3-531-19981-8

UNCED (1992) https://www.un.org/depts/german/conf/agenda21/rio. pdf. Accessed 16 June 2020

Vila LE, Pérez PJ, Morillas FG (2012) Higher education and the development of competencies for innovation in the workplace. Manag Decis 50(9):1634-1648. https://doi.org/10.1108/00251 741211266723

Volz-Peacock M, Carson B, Marquardt M (2016) Action learning and leadership development. Adv Dev Hum Resour 18(3):318-333. https://doi.org/10.1177/1523422316645884

Waddock S (2007) Leadership integrity in a fractured knowledge world. Acad Manag Learn Educ 6(4):543-557. https://doi.org/10.5465/ amle.2007.27694954

Waddock S (2016) Developing humanistic leadership education. Hum Manag J 1(1):57-73. https://doi.org/10.1007/s41463-016-0003-5

Wagner DJ (2018) Digital leadership. Springer Fachmedien Wiesbaden. https://doi.org/10.1007/978-3-658-20127-2

Wang Y, Wu C-H, Parker SK, Griffin MA (2018) Developing goal orientations conducive to learning and performance: an intervention study. J Occupat Org Psychol 91(4):875-895. https://doi. org/10.1111/joop. 12227

Wiedemann H (2008) Das Unternehmen als dialektisches System: Führung und Kommunikation einmal anders betrachtet (3. Aufl., Jubiläumsausg). Rosenberger Fachverl, Leonberg

Wieman CE (2014) Large-scale comparison of science teaching methods sends clear message. Proc Natl Acad Sci USA 111(23):83198320. https://doi.org/10.1073/pnas.1407304111

Willke H (2014) Regieren: Politische Steuerung komplexer Gesellschaften. Stichworte. Springer VS

Woody WD, Daniel DB, Baker CA (2010) E-books or textbooks: students prefer textbooks. Comput Educ 55(3):945-948. https://doi. org/10.1016/j.compedu.2010.04.005

Zillner S, Krusche B (2012) Systemisches Innovationsmanagement: Grundlagen-Strategien-Instrumente. Reihe Systemisches Management. Schäffer-Poeschel Verlag 